\title{
Transformations of phraseological units in Russian and Slovak advertising slogans ${ }^{1}$
}

The paper presents the problem of transformations of phraseological units in modern Russian and Slovak advertising slogans. The primary task of the advertising slogan is to attract the attention of the recipient, to interest a potential buyer, to motivate him to buy certain products. When classical linguistic means and techniques turn out to be ineffective or outdated, the creators of advertising slogans resort to various transformations of the existing material well-known to a certain society, word play and other experiments with language. Transformation of phraseological units is a justified, effective and highly relevant method of attracting attention in various spheres of communication (media, fiction, Internet, blogs, advertising, politics, etc.). This technique has occupied the dominant position in advertising for more than a decade, since fixed expressions or allusions to them appeal to the wisdom of the nation, its origins, and evoke positive images in memory. The purpose of this article is to identify the transformations of phraseological units in advertising using the example of two Slavic languages, to analyse specific examples of transformations created by Russian and Slovak authors, to consider the methods of creating such transformations, to note their features and to draw appropriate conclusions.

Keywords: phraseological unit, transformation, dephraseologization, advertising, advertising slogan.
Рассмотрена проблематика трансформаций фразеологизмов в русских и словацких рекламных слоганах. Рекламный слоган с момента своего существования ставил первостепенную задачу: привлечь внимание рециииента, заинтересовать потенциального покупателя, мотивировать его к покупке. Когда классические языковые средства и приемы оказываются недейственными, устаревшими или малоэффективными, создатели рекламных слоганов прибегают к различным трансформациям существующего и знакомого определенному обществу материала, языковым играм и другим экспериментам с языком. Трансформации фразеологизмов - это оправданный, эффективный и весьма актуальный метод привлечения внимания в различных сферах коммуникации (СМИ, художественная литература, интернет, блоги, реклама, политика и др.). Доминантную позицию в рекламе данный прием занимает уже не одно десятилетие, т.к. устойчивые выражения или аллюзии на них апеллируют кмудрости народа, его истокам, вызывают в памяти положительные образы. Цель настоящей статьи - проследить трансформации фразеологических единиц в рекламе на примере двух славянских языков, проанализировать конкретные примеры трансформаций, созданные российскими и словацкими авторами, рассмотреть приемы создания таких трансформаций, отметить их особенности, сделать соответствующие выводы.

Ключевые слова: фразеологизм, трансформация, дефразеологизация, реклама, рекламный слоган.

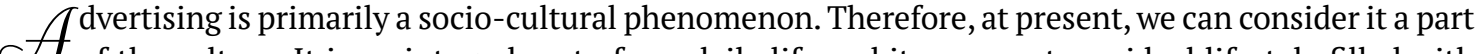
I of the culture. It is an integral part of our daily life and it represents an ideal lifestyle filled with a variety of images. In the case of advertising, we are discussing a form of communication, the purpose of which is to find and influence potential recipients to buy a certain product or service, or to turn their attention to a certain thought. The advertising communication process is complex. Its language has a strong influence on people and their behavior because "words sell". Advertisements convey a message that should influence a large group of unknown or specific recipients within a complex communication system. In this regard, the choice of language means is crucial since specific information is transmitted to recipients with the help of words.

In the past, the original purpose of advertisements was to communicate general information to recipients. In today's highly competitive environment advertisements are primarily a stimulating means with shorter texts, innovative slogans, and headlines designed to catch the attention of the recipient. New words and expressions, emotional lexicon, and linguistic means that do not correspond with the predictability of the rest of the text are part of the creative process. "The more advertising text violates the accepted communicative norms by rebuilding the system of rhetorical expectations, the more it attracts attention" [1. P. 223]. Innovation is also necessary because we are overwhelmed by a huge amount of advertisements on a daily basis. Advertising slogans ought to "stand out"; thereby advertising will not be unnoticed. Language means, together with the physical properties of a text, such as color, size, text

${ }^{1}$ Гаярски Л., Ермачкова О.Е., Спишьякова А. Трансформации фразеологизмов в русских и словацких рекламных слоганах. 
organization, in a complex interaction with images and video, enhance the impact on the recipient. The visual content and design also contribute to the recognition and memorability of a product.

Changes occur in society constantly, which is reflected in all aspects of life, values, as well as in the language itself. In this regard, the language of advertisements must respond promptly to these changes. The form of advertisements itself is also changing. Increasingly, it moves into virtual space and becomes more concise.

From a linguistic point of view, the language of advertisements should be informative, specific, and persuasive. It must attract attention, but at the same time convey the necessary information. The lexicon and other linguistic means usually have positive connotations that emphasize the exceptional qualities of the product and help to create a positive attitude among consumers. Connotations are cultural and emotional associations. Associations, from the point of view of psychology, are connections between two elements (thoughts, events, feelings, etc.), based on which the presentation of the first element activates the other. Associations can be conscious or unconscious. They can be in the form of spontaneous, free associations, or they can be created intentionally which advertising works with.

One of the linguistic means used in advertisements are phraseological units. V.M. Mokienko proposes the following definition of a phraseological unit: "A phraseological unit is understood as a relatively fixed, reproducible, expressive multi-word lexical unit with a non-compositional meaning" [5. P. 5]. The above mentioned phraseological features are noticeable in units with sentence structure as well. We mean proverbs, sayings, weather sayings, but also artificially created units that contain life wisdom of the individual, such as aphorisms, winged expressions and others. Whether it is appropriate to include all these units in phraseology or whether to integrate them in paremiology is not the question of our study. However, we find it necessary to state that for the purpose of our analysis we will approach phraseological units in the broad sense. Paremias, winged expressions and aphorisms will be analysed as well because they are also actively used in advertising and they undergo the same transformations as phraseological units in the narrow sense.

Phraseological units preserve the experience of mankind accumulated over the centuries and the most ancient mythological concepts. They are a kind of refraction in the language of a naive picture of the world and the emotional-value paradigm closely related to it. "The figurative basis of phraseological units reflects the characterological features of the worldview, reflexively correlated by the native speakers with the "language of culture" [8. P. 9]. The meaning of phraseological units based on the internal form and image can be understood only against the background of that material and spiritual culture, that language system, in the context of which phraseological units arise. In other words, the meaning of phraseological units is interpreted, on the one hand, by their background meaning, i.e. the cultural connotation, and on the other hand, the worldview and the material and spiritual culture of humanity are reflected in phraseological units [11.P. 543].

The study of the phraseological fund enables us to ascertain valuable information about the culture and mentality of a given nation because phraseological units are a reflection of its consciousness. They include knowledge about the people's vision of the structure of the world in a concentrated form. At the same time, one of their main functions is to fix the evaluation system of the linguistic culture. They reveal what is considered important by the native speakers and what, on the contrary, is rejected. They are a proven manual, a system of moral and ethical standards. These units have a cultural memory. They influence the adoption of cultural traditions by native speakers as well as the formation of national and cultural mentality. What is culturally significant information is included in these units and they acquire the status of the language of culture [7.P.6]. For these reasons "the studies of different thematic groups of vocabulary and phraseology have been recently injected with a new vigour in areal and comparative linguistics” [9. P. 239].

Phraseological units serve as a source of new, original, and expressive images in the language of advertisements. They are part of the word play and are found in headlines, slogans, or in the text itself. However, they are most common in advertising slogans. Phraseological units are utilized in advertisements for the reason that they are known to most potential recipients. Russian and Slovak phraseological units can be used in their original form without any transformation because they are still expressive enough for advertising purposes, e.g. advertisement of the «Домотехника» chain of stores «Дешево и сердито» (Cheap and angry) or the slogan for Slovak bank ČSOB “Dobrá rada nad zlato" (Good advice over gold).

We also perceive a tendency to use untransformed colloquial phraseological units in advertising slogans in both languages which results from the "struggle" for consumer's attention. This tendency will be 
illustrated as follows: «С нами неудобно?! А нам по барабану!» (It’s not convenient with us?! We don’t care!). Such a shocking slogan was used by mobile operator «Билайн».

We observe a trend towards the usage of informal phraseological units in Slovak advertising slogans as well, e.g. "Nebud' ovca, bud' tava!" (Do not be a sheep. Be a camel). The company producing cigarettes "Camel" has introduced an informal phraseological unit with strong negative connotations "byt' ovca" (to be like a sheep) and promotes an image that a person smoking cigarettes of this brand is independent and does not behave as he is told. Trend of colloquial lexicon in advertising discourse is natural and it corresponds with democratization processes in both studied languages. The shocking slogans we presented will certainly attract the attention of potential buyers.

n our study, we will focus mainly on transformed phraseological units as they are also very productive 1 in advertising slogans and they are of great interest from linguistic point of view. We will understand transformation of phraseological units as any change in the meaning or the form of phraseological unit, after which the unit stays recognizable for recipients.

There are currently a large number of classifications of transformed phraseological units. We have decided to follow classification by V.M. Mokienko and A.M. Melerovich [6]. These authors distinguish semantic and structural-semantic types of transformations. We will illustrate both types on practical material of Russian and Slovak transformed phraseological units in advertising.

Semantic transformations preserve the original structure of phraseological units. They transform semantic level solely through the context. Phraseological unit acquires new shades of meaning in this way or there is an intersection between the literal and figurative meanings of phraseological unit. "Metaphorical meaning of the phraseological unit and its parallel etymological prototype in the form of a free phrase can also be understood as a homonymy, on which the word play is created" [3. P. 214].

Context is crucial in this type of transformation. We need to have a certain background so that the recipient can realize which meaning (literal or figurative) is applied in a specific semantic transformation. The advertising slogan, however, is short and does not provide enough context. This problem is often solved by visual components that support the transformed phraseological unit and present a key to understanding the word play.

popular method of semantic transformation among advertisers is so called dephraseologisation. It is 1 a reverse mechanism to phraseologization. This refers to the process whereby the features of a phraseological unit are lost but the context indicates a connection with a phraseological unit. The phraseological meaning is not applied whatsoever and literal meaning comes to the fore, e.g. «Покажет Кузьку и Кузькину мать» (He will show Kuzka and Kuzka's mother - advertisement for the mobile operator «Билайн»). The literalization of phraseological unit in this advertisement is based on a visual picture of an actor showing a cat and a kitten. The figurative meaning of the fixed phraseological unit «Показать кузькину мать» expressing humorous and ironic threat is absent.

The following slogan «Продаем горячий воздух» (We sell hot air) does not express disapproval meaning of the original phraseological unit «продавать воздух» "to trade in something of a suspicious quality". We see an insertion of a component «горячий», thanks to which dephraseologization is obvious to a recipient in connection to the name of the company «Tермофор» (company for heating stoves). The literal meaning of the phraseological unit is not only actualized but also directly opposed to its idiomatic semantics, which gives the slogan a touch of expressiveness.

We will illustrate also Slovak examples of this interesting method of word play: "Vyhrajte strechu nad hlavou" (Win a roof over your head). The company is not promoting a house as one may think but a roof in its literal meaning as the company "Tondach" sells roofs. The picture of a snail with a shell in form of a roof is presented.

Dephraseologisation is also present in advertisements for "Považský cukor" (sugar producing company): "Som na roztrhanie" (I am about to be torn apart). The idiomatic meaning of a phraseological unit "byt' na roztrhanie" (to have too many responsibilities) is not applied. The dephraseologized phraseological unit implies the paper packaging of the sugar.

nother method to achieve a semantic transformation of phraseological units is double actualization. We speak of a double actualization if phraseological unit is used in the original form, but the literal and 
figurative meanings overlap, which increases the expressiveness of the advertising text significantly. To decode such wordplay, the recipients need a context that will uncover these two layers of meanings. However, in the case of advertising slogans, the context is not usually presented in verbal form because the brevity of the slogan needs to be preserved. The audiovisual components come to support the understanding of the transformed phraseological unit. We will exemplify a few advertising slogans transformed by means of this effective method.

The double actualization can be seen in the slogan of the company "Gilette": «Прояви стальной характер» (Show a steel character). The phrase «стальной характер» (steel character) means "a character or will, characterized by steadfastness". This modification was used in advertisement for a gift set in steel packaging, which was released especially for sports fans. "Gillette" challenged football fans and encouraged them to show their steel character in preparations for the competition in this way.

The advertisement for the bank «Абсолют» has transformed phraseological unit «На птичьих правах» (On the bird's rights - unofficially). The picture of an elephant in a bird's nest plays a meaningful role in the slogan «Чем на птичьих правах держаться, лучше в свой дом перебраться» (It is better to move to your house than to keep on bird's rights) thanks to which the figurative and literal meanings overlap. The memorability of the slogan is also supported by a rhyme. Rhyme "...emphasizes the difference in words that have a similar sound to make one listen and think" [4. P. 990].

Literal and figurative meanings collide also in the following slogan: «Если окна - то БФК! Даже до жирафа дошло» (If windows - then BFK! It even came home to a giraffe). The advertisement depicts a giraffe that approached the window and looked out.

A well-known advertising slogan of Aeroflot airline is based on double actualization as well: «Легок на подъем» (to be easy-going). In this case, it is meant that the aircraft of this airline can fly easily to any place. The company also uses the slogan «Всегда на высоте» (Always on top).

«Чтобы куры не склевали!» (So that the chickens do not peck! - advertisement for deposit programs) in such an advertisement we can trace the transformation of the phraseological unit «Куры не клевали» (Chickens did not peck - big quantity of something). The author of the advertisement intentionally builds word play on the collision of the literal and figurative meanings of a phraseological unit when using nonverbal means (a chicken is shown in the picture).

Creating a double actualization is of particular interest to Slovak advertisers as well, due to high semantic $\checkmark$ richness of phraseological units transformed in this manner. The advertising slogan for banking services "Moji rodičia majú Filipa" (My parents have Filip) actualizes the figurative meaning of Slovak phraseological unit "mat' Filipa" (to be clever). The literal meaning comes to the fore by means of a picture showing a child whose name is apparently Filip since this is the name written on his clothes. The image of a child with the name Filip facilitates the correct interpretation of this advertisement.

Double actualization is an easy way to incorporate the information about the subject of a certain business into the slogan, e.g. "Na betón najlepš́”" (The best for the concrete). This is an advertisement for the construction company "Stavbau". Not only the phraseological meaning of a phraseological unit "Na betón" (To be absolute sure) is implemented but also the literal meaning of a phraseological unit is present in their slogan (betón - concrete as a construction material). In following double actualization the name of the Slovak daily newspaper "Pravda" is incorporated in proverb: "Pravda je len jedna" (The truth is only one).

"Ikea" has also used this innovative way of transforming phraseological units to promote vegan meatballs on the market: "Vyskúšat niečo nové - to chce gule" (To try something new - you need to have the balls; in literal meaning - "meatballs" and in figurative meaning - "courage”).

As seen on the advertising slogans presented the semantically transformed phraseological unit is more expressive than the original form of a phraseological unit: “.... phrase that on the outside corresponds to a fixed phraseological unit, due to this correspondence, attracts a lot of attention. It is perceived as if through the prism of its usual phraseological meaning, which colours the given individual structure to a certain degree" [10. P. 323].

(1) e will proceed to analysing structural-semantic transformations of phraseological units. They offer a wide spectrum of creative and contextual modifications of phraseological units, which can affect the phraseological structure and semantics in several ways.

The most productive structural-semantic transformation in advertising slogans is the component substitution in both analyzed languages. For example, an advertising slogan «Распродажа - это друг человека» 
(A sale is a man's friend - advertisement for a department store); «Тариф - друг человека» (Tariff is a man's friend - advertisement for plane tickets). The above-mentioned examples are modifications of a well-known precedent expression from a popular movie «Бриллиантовая рука»: «Может, там собака - друг человека, а у нас управдом - друг человека» (Маybe, there is a dog a man's friend, but here a caretaker is a man's friend).

We see the paraphrased expression «Дело ясное, что дело темное» (It's clear that it's a dark matter) in the advertisement for beer «Löwenbräu Dunkel»: «Дело ясное, что пиво темное» (It's clear that the beer is dark). Advertisement is based on the substitution of one component of a fixed expression.

The substitution of component is noticeable in the following transformation as well: «Я для тебя роллы сверну» (I'll twist the rolls for you - advertisement for Japanese cuisine restaurants «Япона Хата») - this advertisement is based on the transformation of the phraseological unit «свернуть горы» (to move mountains).

The Slovak mobile operator "4ka" (number 4) has transformed the original proverb "Kto šetrí, má za tri" (literally: Who saves, has it for three). This transformation is based on the substitution of numeral "three" with the name of the mobile operator “4ka” (number four): “Kto šetrí, má za štyri” (literally: Who saves, has it for four).

The KaktusBike retail chain has used the well-known Slovak proverb as their advertising slogan "Najprv práca, potom zábava” (work first, entertainment later), in which we perceive an inversion of components with a substitution: "najprv bike, potom práca" (bike first, work later). The inversion has led to opposite meaning: fun is more important than work.

Wine producer "Terra Parna" has modified a phraseological unit in a more complex manner. At first sight we observe a simple substitution of a component in advertisement "Pozeráme sa na svet cez ružové. Perlivé" (We look at the world through rose-coloured. Sparkling). At the same time, the syntactic structure has been changed. We see a deliberate break of a sentence structure into two separate parts - parcellation, which is typical for colloquial speech, and it adds nuances to the transformation in given example.

Following examples, which undergo syntactic inversions, are also recognized as structural-semantic phraseological transformations, because they modify semantic and structural aspects of phraseological units. The advertisement «Практичным светят деньги» (Money shines for practical - advertisement for «Бинбанк»). The original negative phraseological unit «Не светит» (It does not shine - to have too little chance of success) is transformed into an affirmative statement. As a result, the advertising slogan evokes positive associations among consumers.

The replacement of a negative construction with an affirmative one is also seen in advertising slogan «Можно объять необъятное» (You can embrace the immense - advertisement for loans from the Russian Capital Bank). This transformation refers to the aphorism of Kozma Prutkov «Нельзя объять необъятное» (You cannot embrace the immensity).

In the advertisement for the mobile operator «Билайн» we see an opposite transformation of the fixed expression «тянуть кота за хвост» (to pull the tomcat by the tail), i.e. the transformation of an affirmative phraseological unit to a negative one: «Не тяни за хвост - отправляй быстрее» (Don't pull the tail - send it faster), which serves as an incentive for the consumer to take action. In this particular example the structure and semantics is also changed by the omission of the component «Кот» and the insertion of the second part.

In our examples above, we have already presented a few transformed paremias. Transformation of these fixed units is a popular method of creating advertising slogans. Their usage in original or transformed form is justified, because they evoke associations in consumers of something reliable and true. It is also worth noting that many proverbs and sayings have rhythm and are based on harmony and rhyme. The euphony of an advertising slogan is one of the top priorities of advertisers. The level of communication failures in advertisements with proverbs and sayings is rather low since they are well-known to an average consumer. We will analyze a few more paremias and their creative transformations in advertising slogans.

W e include the following examples in the group of transformed advertising slogans with proverbs and sayings: «Интернет до Киевской доведет» (The Internet will bring you to Kyivskaya). Mobile operator «Билайн» has creatively approached the modification of the proverb «Язык до Киева доведет» (Language will bring you to Kyiv). The advertisement for the «Билайн» «От подарка не уйдешь» (You can't get away from a gift) is also based on the transformation of the proverb «От судьбы не уйдешь» (You can't get away from fate). This transformation is based on the substitution of a component and the use of a precedent text. 
The popular phrase used to emphasise the importance of punctuation «Казнить нельзя помиловать» (To pardon impossible to execute) has motivated following parallel advertising slogans: «Молчать нельзя комментировать» (To be quiet impossible to comment - advertisement for «Билайн»); «Копить нельзя купить» (To save impossible to buy - advertisement for «Абсолют банк»).

We observe an allusion to proverb «Все дороги ведут в Рим» (All roads lead to Rome) in the advertisement «Все дороги ведут к нам» (All roads lead to us - advertisement for the printing house). Perhaps the precedent text to the transformation was «Все дороги ведут к людям» (All roads lead to people) from the work of A. de Saint-Exupery «The Little Prince».

The transformation of paremias is also typical for Slovak advertising. Here are examples of advertisements for mobile provider "Juro": "Vtáka poznáš po perí, Jura po predvol'be” (You can recognize a bird by feathers, Juro by area code) (original: Podl'a peria poznáš vtáka, podl'a reči poznáš človeka - You can recognize a bird by feathers and a person by speech); "Dvakrát meraj a lacno volaj" (Measure twice and call cheaply) (original: Dvakrát meraj a raz rež - Measure twice and cut once).

“Kol'ko topánok máš, tol'kokrát si človekom” (How many shoes you have, so many times you are a human being - advertisement for an e-shop moda.sk). This slogan comes from a proverb "Kolko jazykov vieš, tol'kokrát si človekom" (How many languages you know, so many times you are a human being). The presented examples both in Russian and Slovak suggest a high frequency of component substitution among transformations of paremias.

Oot only proverbs are transformed in advertising. Other precedent texts find their application in transformed form as well. Some transformations of precedent texts are aimed at a wide range of recipients and can be identified across cultures. We will illustrate such a text on the material of Slovak advertising campaign of the delivery service "Bistro.sk", which used a motif from the fairy tale about the Little Red Riding Hood, which is known to all children and adults in the European context. The advertisement presents a following dialogue between The Little Red Riding Hood and a wolf in disguise of her grandmother: "Babička prečo máš také vel'ké uši? Aby som lepšie počula. Prečo máš v ruke mobil? Aby som mohla objednat' na bistro.sk” (Grandma, why do you have such big ears? To hear better. Why do you have a cell phone in your hand? So that I can order on bistro.sk).

On the other hand, "Radoma" company which specialises in frozen products has focused on folk motifs and transformed a well-known Slovak folk song. Slovak native speakers immediately recognize the song "Slovenské mamičky, pekných synov máte” (Slovak mothers, you have handsome sons) in following modification "Slovenské mrazničky, chutné jedlá máte” (There is delicious food in Slovak fridges). Motifs of folk art are often used in Slovak advertisement because they are easily identified and remembered. They evoke familiar and pleasant associations among recipients.

Advertisements and their slogans must be attractive and easy to remember to influence the target audience. The entire language of advertisements is based on this assumption along with visual and sound components. The study has shown that phraseological units are highly effective means for carrying out the persuasive function of advertising language, as they are a "mirror" of the cultural aspects of society. An active process of phraseologization takes place in the language of advertisements in order to create new, original, and expressive images, to enhance the potential impact on the recipient. They can be a source of new fixed expressions that have not been fixed before.

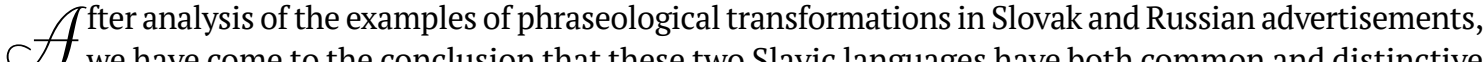
- we have come to the conclusion that these two Slavic languages have both common and distinctive features. Both semantic and structural-semantic types of transformations were detected. Double actualization and dephraseologization are equally used in Russian and Slovak advertising slogans, because they both are effective in creating word play in connection with the context provided by visual elements. However, we have noted a more active tendency to incorporate the information about the subject of a certain business into the slogan or the name of the company in Slovak language.

Structural-semantic transformations are largely represented in both languages by component substitution, which is the easiest way to transform a phraseological unit and it allows the authors to adjust the phraseological unit for the needs of a certain context or a product. Sporadically component substitution was followed by other modifications of structural-semantic nature, such as omission, insertion, parcellation, inversion. 
Transformations of phraseological units predominate to a large extent in advertisements of mobile operators in both Slovak and Russian languages. In both languages, the substandard lexicon is used in the formation of advertising slogans based on phraseological units for the purpose of stronger expressiveness and eccentricity.

In terms of the quantitative aspect, transformations of proverbs and sayings dominate in Slovak advertising. Slovak advertising is also known for a tendency to use and to transform folk motifs which are typical for Slovak culture. They are well-accepted by Slovak native speakers. In Russian advertising some fixed expressions seem to be more productive in phraseological transformations (for example: «Казнить нельзя помиловать»).

Phraseological units are undoubtedly an important part of advertising texts and slogans, because they enable the immediate recognition of native speakers and their rapid memorization and subsequent reproduction. "Phraseological units not only make language expression more interesting, more engaging, but they also add argumentative power and persuasiveness and the recipient can be more effectively influenced through their incorporation into context" [2. P. 109]. The function of advertising is not only to inform, but above all to influence the addressee. Therefore, the transformations of phraseological units are an ideal choice for this purpose.

\section{References}

1. Eco U. Otsutstvujushhaja struktura. Vvedenie v semiologiju. TOOTK “Petropolis”, 1998. $432 \mathrm{~s}$.

2. Grigorjanová T. Frazeologické metamorfózy v slovensko-ruskom politickom diskurze // Slovo v slovníku: aspekty lexikálnej sémantiky - gramatika - štylistika (pragmatika). Bratislava: Veda, 2012. P. 109-117.

3. Grigorjanová T., Spišiaková A. Štruktúrno-sémantické frazeologické modifikácie v slovenskom a ruskom mediálnom texte // Slavica Slovaca. 2020.Vol. 55. No. 2. P. 211-222.

4. Grominová A. Motif of world transfiguration in Ivan Zhdanovs poem Orans // Quaestio Rossica. 2019. Vol. 7. No. 3. P. 983-991.

5. Mokienko V.M. Slavianskaia frazeologiia. Moscow: Vysshaia shkola, 1989. $287 \mathrm{~s}$.

6. Mokienko V.M., Melerovich A.M. Frazeologizmy v russkoi rechi: Slovar. Moscow: Russkie slovari, 1997. $864 \mathrm{~s}$.

7. Novoseltseva V.A. Konceptualizaciia vremeni v russkoi frazeologii i chudozhestvennyh tekstach (dissertaciia). Krasnodar: Kubanskii gosudarstvennyi un-t, 2005.

8. Teliya V.N. Pervoocherednye zadachi i metodologicheskie problemy issledovaniia frazeologicheskogo sostava iazyka v kontekste kul'tury // Frazeologiia v kontekste kul'tury. Moscow: Iazyki russkoi kul'tury, 1999. S. 13-24.

9. Tyshchenko $O$. The linguistic and cultural image of weaving craft in paroemias and phrasemes: East and West Slavic Context // Slavica Slovaca. 2020. Vol. 55. No. 2. P. 238-256.

10. Shmelev D.N. Sovremennyi russkii iazyk: Leksika: ucheb. posobie. Moscow, 2019. $336 \mathrm{~s}$.

11. Shuczin' L.L. Otrazhenie nacional'no-kul'turnogo aspekta v kitaiskich i russkich frazeologizmach // Nauchnye vedomosti. Seriia: Gumanitarnye nauki. 2018. T. 37. No. 4.

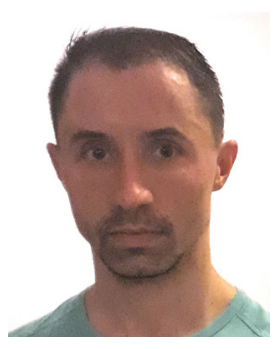

Gajarsky Lukas,

Candidate of Philology, Senior Lecturer of the Russian Studies Department University of Ss. Cyril and Methodius in Trnava (Slovakia)

e-mail: lukas.gajarsky@ucm.sk

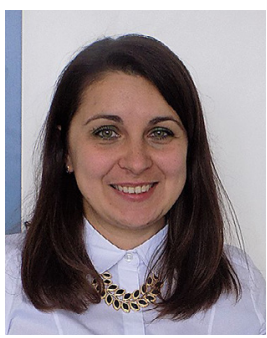

Iermachkova Olga E., Candidate of Philology, Senior Lecturer of the Russian Studies Department University of Ss. Cyril and Methodius in Trnava (Slovakia)

e-mail: olga.iermachkova@ucm.sk

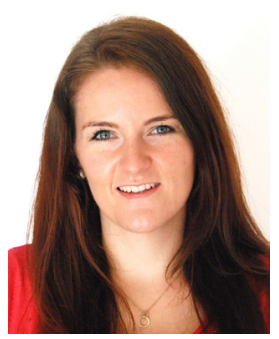

Spisiakova Andrea, Candidate of Philology, Senior Lecturer of the Russian Studies Department University of Ss. Cyril and Methodius in Trnava (Slovakia) e-mail: andrea.spisiakova@ucm.sk

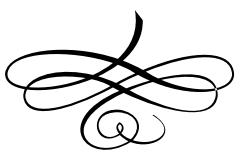

